\title{
ANALISIS PENDIDIKAN ISLAM DI INDIA DAN PERBANDINGANNYA DENGAN PENDIDIKAN DI INDONESIA
}

\author{
Agus Setiawan \\ Dosen IAIN Samarinda, Kalimantan Timur, Indonesia \\ agus.rdat@gmail.com
}

\begin{abstract}
Abstrak
India mempunyai universitas pertama di dunia dengan 1000 dosen berdiri Pada abad 6 dan 7. Di India memiliki perpustakaan yang buka 24 jam. Sehingga kapanpun bisa belajar atau membaca di perpustakaan tersebut. Ada banyak pelajaran di luar ruangan kuliah. Pendidikan Islam di India, mengalami masa-masa yang sulit, karena dianggap minoritas dan dianaktirikan oleh pemerintah. Namun dengan semangat dari minoritas muslim ini, maka sebagian mendesak untuk mereformasi pendidikan Islam di India.

Faktanya bahwa pendidikan Islam di India seperti di Madrasah telah berkembang dengan kolaborasi kurikulum madrasah kepada kurikulum modern, sehingga banyak siswanya yang belajar disana. Tercatat tidak hanya siswa muslim yang belajar, namun kebanyakan malahan siswa beragama Hindu yang belajar di madrasah. Meskipun disebut madrasah (sekolah Islam), orang-orang di daerah melihatnya seperti sekolah reguler yang baik. Seperti Madrasah Orgram yang terletak $125 \mathrm{~km}$ utara ibukota negara bagian, Kolkata, mengatakan bahwa sebagian besar kurikulum modern telah membuat lembaga semakin populer dalam masyarakat mayoritas Hindu. "Orang-orang biasa percaya bahwa madrasah adalah tempat di mana siswa diajarkan hanya pelajaran agama, dan hal itu tidak ada hubungannya dengan pendidikan modern. Pengakuan dari guru disana bahwa selama beberapa tahun telah bekerja untuk mengubah gagasan mereka. Di India berbeda dengan di Indonesia ketika anak selesai sekolah/belajar di sekolah. Di India ketika guru pulang mengajar, tidak langsung pulang ke rumah. Tetapi, Guru diundang oleh orang tua siswa untuk menginap/berkunjung ke rumah orang tua siswa. Untuk mengajarkan pelajaran tambahan di rumah siswanya. Guru dilayani dengan baik oleh keluarga siswa diberikan pelajaran dengan cara memanggil guru ke rumah untuk memberikan pelajaran tambahan.
\end{abstract}

Kata Kunci : Pendidikan Islam, India, Perbandingan, Pendidikan Indonesia.

\section{A. Pendahuluan}

Berdasarkan dari hasil wawancara dengan teman saat sedang mengajar di sebuah lembaga pendidikan di Palia Kalan, Uttar Pradesh Kota Lucknow India 
Agus Setiawan: Analisis Pendidikan Islam di India dan Perbandingannya dengan Pendidikan di Indonesia.

Utara. ${ }^{1}$ Hasil informasi tersebut bahwa Muslim India yang ada di daerah tersebut, mereka belajar mengenai Keislaman itu variatif, tergantung arahan dari orang tuanya. Ada yang belajar, dengan orang tuanya secara langsung (belajar sholat, baca qur'an) dan ada juga yang langsung ke mesjid belajar bersama "Maulana" (sebutan orang sini) di tempat kita semacam Kyai. Dan ada juga yang belajar ke home tuition, semacam kursusan khusus untuk belajar keislaman. Bahkan, kalau di tempat lain ada juga sekolah yang langsung memfasilitasi mengenai ajaran keislaman. Seperti di Bangalore, India. Iqra International School. Sekolah khusus untuk belajar keislaman. Jadi, anak-anak muslim India sini belajar dengan orang tuanya, di mesjid, atau dengan Maulana, dan bisa pergi ke home tuition tadi sedangkan untuk di perguruan tinggi mereka belajar sesuai dengan major yang mereka ambil. Misalnya: Islamic law. Maka, mereka akan mengkaji mengenai hukum Islam (hal ini, tidak jauh berbeda dengan kondisi di Indonesia). Dan untuk kampus yang recommended bagi India Muslim, yakni Aligarh Muslim University (AMU). Kampus yang mayoritasnya mahasiswa Muslim yang studi di sana, tidak hanya Muslim India tapi dari belahan dunia lainnya. Berdasarkan hasil sharing (Via WhastApp) dengan Muslim yang sedang studi S3 di Mumbai. "Pertama belajar mengenai keislaman yakni tentang bahasa arab (readingnya) agar bisa membaca Alqur'an. Dan hal itu, yang sering ditekankan dalam Pendidikan Islam di sini (Mengenai membaca Al-qur'an). Setelah itu, tergantung individu masingmasing, mereka mau melanjutkan atau tidak, sampai mendapat gelar "Hafidz Maulana Qori".

India merupakan salah satu negara yang mempunyai peradaban tertua di dunia yang penuh dengan tradisi, aliran keyakinan, seni dan kebudayaan yang beraneka ragam. Selama ini India dikenal sebagai pusat dari ajaran agama Hindu, namun perlu kita ketahui bahwa Islam telah menjadi agama terbesar kedua di India. Islam berkembang dari masa sebelum kerajaan Mughal hingga

\footnotetext{
${ }^{1}$ Wawancara dengan Muhammad Wahid, Pengajar Indonesia dari IAIN Samarinda (Magang beberapa bulan), Tanggal. 24-3-2018.
} 
Agus Setiawan: Analisis Pendidikan Islam di India dan Perbandingannya dengan Pendidikan di Indonesia.

datangnya penjajah Inggris ke India, kemudian India merdeka dan Islam tetap tumbuh disana. Walaupun saat ini menjadi agama minoritas di India namun dikatakan terbanyak, tentu tidak dipungkiri Islam menjadi agama yang cukup berpengaruh bagi penduduk India lainnya. Di Ensiklopedi Oxford, Dunia Islam Modern menyebutkan bahwa di India merupakan salah satu negara berpenduduk Muslim terbesar setelah Indonesia. ${ }^{2}$

Sebagai negara besar, India merupakan salah satu Negara di kawasan Asia Selatan yang terletak di Anak Benua India. India merupakan negara terbesar ketujuh berdasarkan ukuran wilayah geografis dan memiliki jumlah penduduk hampir 1 milyar lebih. Mayoritas penduduk merupakan pemeluk dari agama Hindu.

Masuknya Islam di India pada mulanya dikenalkan oleh Umar bin Khatab pada abad ke-7 M, yang kemudian diteruskan oleh Khalifah Arrasyidin dengan cara damai. Setidaknya ada 2 periode yang dikemukakan oleh Dudung Abdurahman, dkk, mengenai pengaruh Islam di India yaitu periode zaman Nabi Muhammad sampai berakhirnya dinasti Ghuri dan periode kesulthanan Delhi. ${ }^{3}$

Pada perkembangan pendidikan di India. Sebelumnya dikenal sistem pendidikan Hindu India kuno berpusat pada pelajaran kepercayaan agama dan sistem kasta. ${ }^{4}$ Hingga saat ini sistem kasta masih tetap berlaku, dan untuk Muslim sendiri disana dianggap sebagai kasta yang lebih jelek dari kasta paria. Buruknya lagi pada saat penjajahan Inggris maka hukum Islam seakan-akan berusaha dihapuskan, begitu pula pada aspek pendidikan Islamnya.

Dikatakan oleh M. Ali Kettani, bahwa sejak diposisikan di bawah buruknya Imperium Inggris, Muslim melakukan usaha besar di bidang pendidikan, Muslim di India pada waktu itu membangun ratusan sekolah dan

\footnotetext{
${ }^{2}$ Ensiklopedi Oxford, Dunia Islam Modern, Jilid 2, Diterjemahkan oleh Eva Y.N, dkk, (Bandung, Mizan, 2002), h. 298.

${ }^{3}$ Dudung Abdurahman, et.al, Sejarah Peradaban Islam dari Masa Klasik Hingga Modern (Yogyakarta: LESFI, 2009), h. 165.

${ }^{4}$ Drajat Zakiah, Metodologi Pengajaran Agama Islam (Jakarta: Bumi Aksara, 2008), h. 4
}

Jurnal Ilmiah Al QALAM, Vol. 12, No. 2, Juli-Desember 2018 
Agus Setiawan: Analisis Pendidikan Islam di India dan Perbandingannya dengan Pendidikan di Indonesia.

banyak perguruan tinggi berbasis Islam. Seperti perguruan tinggi terkemuka yaitu Universitas Aligarh di Uttar Pradesh, Jamia Milia di New Delhi, Osmania College di Hyderabad. Ini membuktikan ada suaha keras dan luar biasa dari Muslim di India. Namun sejak kemerdekaan India, maka pemerintahan federal dan negara bagian mengajukan rancangan undang-undang amandemen, keduanya berusaha mengambil semua tindakan untuk menghapus dan meniadakan ciri Islam pada lembaga-lembaga Islam yang telah dibangun oleh Muslim India. ${ }^{5}$

Berdasarkan penelitian Intakhab Alam Khan, Muslim Education in PostIndependent India Issues, Factors and Prospects, dalam Journal of Education and Learning. Pendidikan Muslim selalu menjadi masalah serius meskipun ketersediaan begitu banyak institusi akademis di institusi umum dan minoritas pada khususnya. Kondisi pendidikan Muslim yang buruk tidak dapat dikaitkan dengan pemerintah saja, tetapi masyarakat, rumah, ekonomi, motivasi, pekerjaan dan faktor-faktor serupa. ${ }^{6}$

Untuk memberikan gambaran yang jelas tentang Muslim di India. Pada tahun 1902 merupakan peristiwa penting dan ini adalah sebuah prestasi pada pendidikan Islam di India dengan pembentukan Asosiasi Pendidikan Muslim India Selatan di Madras. Bahwa disana ada 75 sekolah dasar Muslim diakui. Juga untuk sekolah menengah ada 30 dibawah kepengurusan muslim. Sedangkan untuk Pada tahun 1972-1973, dari 172 perguruan tinggi di Negara Bagian itu, ada sebelas perguruan tinggi didirikan dan di kelola oleh orang Muslim. $^{7}$

Dengan demikian pendidikan Islam di India menjadi tuntutan tersendiri dari penduduk muslim India kepada pemerintah untuk mengevaluasi sehingga dapat berjalan baik bagi muslim dan pemerintahan di India saat ini.

${ }^{5}$ M. Ali Kettani, Minoritas Muslim di Dunia Dewasa Ini (Jakarta: PT.Raja Grafindo Perkasa, 2005), h. 157.

${ }^{6}$ Intakhab Alam Khan, Muslim Education ...., h. 63.

${ }^{7}$ M. Ali Kettani, Minoritas...h. 176.

Jurnal Ilmiah Al QALAM, Vol. 12, No. 2, Juli-Desember 2018 
Agus Setiawan: Analisis Pendidikan Islam di India dan Perbandingannya dengan Pendidikan di Indonesia.

\section{B. Pembahasan}

\section{Sejarah Singkat India}

a. Awalnya Kerajaan di India

Dalam sejarahnya, India merupakan wilayah dengan berbagai macam kebudayaan yang berkesinambungan selama 5000 Tahun. Kebudayaan dilembah Indus (3000 SM sd. 1500 M) telah diikuti dengan zaman Vedic, yang menggunakan bahasa sansekerta (1500 SM sd. 5000 SM). Terdiri dari kerajaan yang turun termurun dikuasai oleh raja. Hingga keaadan ini diikuti oleh zaman kekuasaan Islam sekitar abad ke $9 \mathrm{M}$ dan diikuti dengan kedatangan bangsa Eropa, terutama bangsa Inggris, pada abad ke-17 M.

Pada tanggal 15 Agustus 1947, Inggris memberikan kemerdekaan kepada India. Pada tanggal 26 Januari 1950, India resmi menjadi republik India dengan presiden sebagai kepala negara dan perdana menteri sebagai kepala pemerintahan. Usaha-usaha dan aktivitas diplomatisnya, seperti Konferensi Asia-Afrika, Gerakan Non-Blok, dan sebagainya menetapkan India sebagai salah satu negara terkemuka dalam dunia ketiga. ${ }^{8}$

b. Letak Geografis dan Sistem Pemerintahan India

India adalah negara besar ke tujuh dan mempunyai penduduk kedua terbanyak di dunia. India berada di Asia selatan dan dikelilingi oleh Pakistan, Afganistan, Cina, Buthan, Myanmar, dan Bangladesh, Samudra Hindia, Laut Arabia, dan Teluk Bengal sebagai batas lautnya. Daratan india terbagi atas tiga macam daerah geografis: daerah pegunungan Himalaya, daratan rendah yang dibentuk oleh sungai Indus-GanggaBrahmaputra, dan disebelah selatan terdapat semenanjung daratan tinggi Deccan. ${ }^{9}$

\footnotetext{
${ }^{8}$ Abdul Hayyie al-Katttani dkk, Study In Islamic Countries Panduan Lengkap Kuliah di Negara-negara Islam, (Jakarta: Gema Insani, 2009 ), h. 254.

${ }^{9}$ Abdul Hayyie al-Katttani dkk, Study..., h. 255.
}

Jurnal Ilmiah Al QALAM, Vol. 12, No. 2, Juli-Desember 2018 
Agus Setiawan: Analisis Pendidikan Islam di India dan Perbandingannya dengan Pendidikan di Indonesia.

India dibagi menjadi 27 negara bagian dan 7 wilayah kesatuan. Negara-negara bagian tersebut mempunyai kekuasaan otonomi sendiri yang cukup luas.

Ibu kota India adalah New Delhi. Merdeka saat 26 Januari 1950. Sistem Pemerintahan yaitu Republik Parlementer. Perdana menteri saat ini yaitu Narendra Modi, menjabat mulai 26 Mei 2014 sampai saat ini. Bahasa yang digunakan saat ini Hindi dan Inggris. Luas daerah India yaitu seiktar 3.287.590 km persegi, India merupakan Negara ketujuh terluas di dunia, serta pendapatan kedua setelah Cina. Dengan penduduk berjumlah sekitar 1.274.590.000 jiwa, dengan kepadatan sekitar 83,6 jiwa/km. Mayoritas penduduk India beragama Hindu yaitu sebesar $83 \%$, dan agama terbanyak kedua di India yaitu Islam sebesar $13-15 \%,{ }^{10}$ dan selebihnya beragama Kristen, Siktis dan lainnya. Kondisi ekonomi di India bertumpu pada sektor peternakan mencapai $34 \%$ dari pendapatan negara, sedangkan pertanian $69 \%$ mampu menyerap tanaga kerja yang ada. ${ }^{11}$

c. Keadaan Iklim dan Cuaca Negara India

Iklim dan cuaca di India berbeda dari satu wilayah dengan wilayah yang lain. Beberapa wilayah, termasuk daerah pesisir, mempeunyai iklim dan cuaca yang seragam sepanjang tahun. Meskipun demikian, ada beberapa wilayah di India yang mempunyai iklim dan cuaca yang nyaman, seperti kota-kota diwilayah utara dan Bangalore di sebelah selatan. Selain daripada wilayah tersebut, hampir semua daerah akan terasa sangat panas pada musim panas.

Secara umum, iklim dan cuaca di India bisa dibagi sebagai berikut:

1) Bulan Maret sampai dengan Juni: Musim panas.

2) Bulan Juni sampai dengan Oktober: Musim penghujan.

\footnotetext{
${ }^{10}$ Intakhab Alam Khan, Muslim Education in Post-Independent India Issues, Factors and Prospects, Journal of Education and Learning, Vol. 10 (1), 2016, h. 65.

${ }^{11}$ https://id.wikipedia.org/wiki/India,danhtps://ms.wikipedia.org/wiki/PerdanaMe nteriIndia, Diakses pada 13-3-2018.
}

Jurnal Ilmiah Al QALAM, Vol. 12, No. 2, Juli-Desember 2018 
Agus Setiawan: Analisis Pendidikan Islam di India dan Perbandingannya dengan Pendidikan di Indonesia.

3) Bulan November sampai dengan Februari: Musim dingin.

4) SDM di Negara India.

d. Bahasa dan Budaya Masyarakat di Negara India.

Bahasa Hindi adalah bahasa resmi pemerintahan dan Bahasa Inggris juga dipakai sebagai bahasa penghubung. Selain itu ada sekitar 16 bahasa lainnya selain Hindi dan Inggris yang ditetapkan di dalam undangundang sebagai bahasa resmi yang boleh dipakai dalam pelaksanaan pemerintahan dinegara-negara bagian.

Masyarakat India pada umumnya ramah dan santai. Banyak dari mereka yang berani memperkenalkan diri terlebih dahulu sebelum diminta untuk bicara. ${ }^{12}$

\section{Pendidikan Islam di India}

a. Masuknya Islam dan Pembaharu Pendidikan Islam

Sejarah peradaban Islam di India terbilang panjang. Meskipun begitu, masuknya ajaran Islam ke India bisa diklasifikasikan dalam tiga gelombang, yakni dibawa orang Arab pada $7 \mathrm{M}$, orang Turki pada $12 \mathrm{M}$, dan abad ke-16 M oleh orang Afghanistan. Menurut catatan sejarah, Islam mulai masuk ke India pada era pemerintahan Khalifah Umar Bin Khathab. Pada tahun $16 \mathrm{H}$ (636 M). Khalifah Umar mengirimkan pasukan ke Persia di bawah pimpinan Sa'ad bin Abi Waqas. Ia berjuang selama 16 tahun, akhirnya dapat menguasai seluruh Persia, kemudian diperluas ke Khurasan dan diteruskan ke India. ${ }^{13}$

Sebelum kedatangan agama Islam, orang-orang Arab telah mengadakan komunikasi dengan orang India. Komunikasi mereka melalui jalur sutra (Silk Road) perdagangan lewat daratan. Hasil yang terkenal pada

\footnotetext{
${ }^{12}$ Abdul Hayyie al-Katttani dkk, Study..., h. 256.

${ }^{13}$ Abdul Syukur al-Azizi, Kitab Sejarah Peradaban Islam Terlengkap (Yogyakarta: Saufa, 2014), h. 352-353.
}

Jurnal Ilmiah Al QALAM, Vol. 12, No. 2, Juli-Desember 2018 
Agus Setiawan: Analisis Pendidikan Islam di India dan Perbandingannya dengan Pendidikan di Indonesia.

waktu itu adalah produksi pembuatan pedang dari tanah Arab yaitu Saif Muhammad artinya: "Pedang yang disepuh secara Hind". ${ }^{14}$

Bidang lain yang mengalami kemajuan adalah bidang ilmu pengetahuan, ekonomi, seni, sastra dan kebudayaan. Keindahanpada seni lukis dan seni ukir terlihat pada bangunan Mesjid Quwwatul Islam, QutubMinar, Qilal Qirwan, gedung perkuliahan, taman Shalimar dan Makan TajMahal.

Tanpa kedatangan agama Islam ke India mungkin tidak akan pernah ada rekaman sejarah mengenai masa lalu India. Bahasa sehari-hari di India banyak coraknya, ada bahasa India, Sanskerta, dan Parsia. Dengan pengaruh bangsa Arab terciptalah bahasa lain India yaitu bahasa Urdu. Oleh para saudagar. Saudagar ini pula pada tahap awal yang menanamkan benih aqidah. Sehingga menurut Ahmad Syafi'i Ma'arif bahwa setidaknya ada hubungan antara Islam dan India yang menghasilkan bentuk asimilasi yang saling membutuhkan satu sama lain dalam banyak bidang diantaranya ilmu pengetahuan, seni bangunan, dan bahasa. ${ }^{15}$

Begitupula gaung pembaruan pemikiran Islam yang dipelopori oleh para pembaru di dunia Islam, bergema ke seluruh dunia Islam, demikian juga gema pembaharuan pendidikan Islam yang disponsori oleh Muhammad Abduh dan murid-muridnya, Muhammad Ali Pasha dari Mesir, Sultan Mahmud II dari Turki, Sayyid Ahmad Khan dari India. ${ }^{16}$

Diantara tokoh-tokoh pembaruan di India ${ }^{17}$ seperti Sayyid Ahmad Khan, Sayyid Amir Ali, Muhammad Iqbal, Muhammad Ali Nijah. ${ }^{18}$

\footnotetext{
${ }^{14}$ Hamka, SejarahUmatIslam, (Jakarta: Bulan Bintang,1981), Cet.Ke-3, Jilid1, h. 117.

${ }^{15}$ Ahmad Syafi'i Ma'arif, Pemikiran dan Peradaban Islam (Yogyakarta: Safiria Insania Press, 2007), h. 37-40.

${ }^{16}$ Haidar Putra Daulay, Dinamika Pendidikan Islam di Asia Tenggara (Jakarta: Rineka Cipta, 2009), h. 182.

${ }^{17}$ Yusran Asmuni, Pengantar Studi Pemikiran dan Gerakan Pembaharuan dalam Dunia Islam (Jakarta: Raja Grafindo Persada, 1998), h. 31-48.
}

Jurnal Ilmiah Al QALAM, Vol. 12, No. 2, Juli-Desember 2018 
Agus Setiawan: Analisis Pendidikan Islam di India dan Perbandingannya dengan Pendidikan di Indonesia.

Misalnya, Sayyid Ahmad Khan Ibnul Muttaqi Ibnul Hadi Al-HasanAdDahlawi lahir di India pada tanggal17Oktober 1817. Ayahnya bernama Mir Muttaqi adalah seorang pemimpin agama. ${ }^{19}$ Ia termasuk keluarga Aristokrat Nabillah. Sayyid Ahmad Khan menurut silsilah berasal dariketurunan Husein, cucuNabi Muhammad melalui Fatimah danAli. Sedangkan neneknya bernama Sayyid Hadi, salah seorang pembesar istana pada zaman Almaghir (1754-1759) ${ }^{20}$

Islam yang selalu dipandang radikal oleh Barat, tidak tergambar di New Delhi. Pemerintah India bahkan memberlakukan hari libur saat perayaan hari besar agama Islam. Sementara dari sisi pakaian, meski tak berjilbab, para muslimah di New Delhi tetap menggunakan baju panjang yang relatif tertutup. New Delhi juga menjadi tempat berkumpulnya komunitas Muslim. Meski beragam, tapi komunitas itu cenderung seragam yakni memiliki menganut mahzab Hanafi dan Syafi'i. Dan hanya beberapa saja yang bermazhab Syiah.

b. Kebijakan Pemerintah pada Pendidikan Islam India

Pendidikan Islam di India ikut dipengaruhi oleh kebijakan pendidikan nasional di India. Makanya banyak dari lembaga pendidikan Islam dasar atau disebut Makatib atau Madaris berusaha untuk memodern kan kurikulum pendidikan madaris dengan kolaborasi kurikulum nasional dan kurikulum madaris. Sehingga menjadi acuan dan bahwa perhatian bagi pendidikan anak. Tidak hanya anak Muslim yang masuk sekolah madaris, namun banyak juga anak non muslim yang sekolah disana.

\footnotetext{
${ }^{18}$ Fadil SJ, Pasang Surut Peradaban Islam dalam Lintas Sejarah (Malang: UIN Malang Press, 2008), h. 267-273.

${ }^{19}$ Mukti Ali, Alam Pikiran Islam Modern di India dan Pakistan (Bandung: Mizan, 1998), h. 54.

${ }^{20}$ HarunNasution,PembaharuandalamIslamSejarahPemikirandanGerakan(Jakart a:BulanBintang, 1982),h. 165.
}

Jurnal Ilmiah Al QALAM, Vol. 12, No. 2, Juli-Desember 2018 
Agus Setiawan: Analisis Pendidikan Islam di India dan Perbandingannya dengan Pendidikan di Indonesia.

c. Kurikulum Pendidikan Islam India

Saat ini kurikulum pendidikan Islam di India telah berkembang dan mengalami modernitas sehingga pendidikan Islam di sana mengikuti tren untuk berkolaborasi dengan kurikulum nasionalnya, sehingga dapat dilihat bahwa pendidikan Islam di India saat ini dengan tingkat dasar seperti Madaris itu menjadi tujuan bagi penduduk disana menyekolahkan anaknya. Belum lagi dengan terkenalnya perguruan Tinggi Islam disana sampai seluruh dunia, seperti Universitas Muslim Aligarh, Jamia Millia Islamia, Universitas Islam Darul Huda, dll. Perlu juga diketahui bahwa perguruan tinggi Islam di India tersebut bahkan menyaingi perguruan tinggi seperti Universitas New Delhi.

\section{Analisis dan Hasil Perbandingan Pendidikan India dan Indonesia}

1. Kondisi Pendidikan Islam India dan Indonesia

India mempunyai universitas pertama di dunia dengan 1000 dosen berdiri Pada abad 6 dan 7. Di India memiliki perpustakaan yang buka 24 jam. Sehingga kapanpun bisa belajar atau membaca di perpustakaan tersebut. Ada banyak pelajaran di luar ruangan kuliah.

Pendidikan Islam saat ini di India, mengalami masa-masa yang sulit, karena dianggap minoritas dan dianaktirikan oleh pemerintah. Namun dengan semangat dari minoritas muslim ini, maka sebagian mendesak untuk mereformasi pendidikan Islam di India.

Faktanya bahwa pendidikan Islam di India seperti di Madrasah telah berkembang dengan kolaborasi kurikulum madrasah kepada kurikulum modern, sehingga banyak siswanya yang belajar disana. Tercatat tidak hanya siswa muslim yang belajar, namun kebanyakan malahan siswa beragama Hindu yang belajar disana. "Meskipun disebut madrasah (sekolah Islam), orang-orang di daerah melihatnya seperti sekolah reguler yang baik. 
Agus Setiawan: Analisis Pendidikan Islam di India dan Perbandingannya dengan Pendidikan di Indonesia.

Di India berbeda dengan di Indonesia ketika anak selesai sekolah/belajar di sekolah. Di India ketika guru pulang mengajar, tidak langsung pulang ke rumah. Tetapi, Guru diundang oleh orang tua siswa untuk menginap/berkunjung ke rumah orang tua siswa. Untuk mengajarkan pelajaran tambahan di rumah siswanya. Guru dilayani dengan baik oleh keluarga siswa diberikan pelajaran dengan cara memanggil guru ke rumah. Untuk memberikan pelajaran tambahan.

Setelah jam 11 malam di India tidak boleh pergi ke diskotik atau berkumpul bernyanyi dengan teman-temannya. Kalau pun ada hanya anak orang kaya saja yang melakukan. Anak-anak dilarang keluar rumah, karena berbahaya. Kalaupun ada temannya yang ulang tahun kemudian diundang dalam acara tersebut, maka anak-anak diberikan kesempatan dengan perjanjian hanya satu atau dua jam saja. Anak-anak harus pulang kembali ke rumah.

\section{Sistem Pendidikan India dan Indonesia}

Sistem pendidikan India sedikit berbeda dengan Indonesia, setidaknya dilihat dari usia pendidikan tingkat SD sampai Menengah. Di India menggunakan sistem 10 tahun pembelajaran. Terbagi dalam 3 jenjang, yaitu primary (5 tahun), upper primary (3 tahun), dan secondary (2 tahun). Struktur pendidikan sekolah yang seragam tersebut telah di adobsi oleh seluruh Negara bagian dan teritori India. Ini juga berlaku untuk pendidikan konvensionalnya dan pendidikan Islamnya. Karena keduanya di bawah kebijakan Nasional pemerintah India.

Berbeda dengan Indonesia yang mewajibkan 6 tahun di SD, 3 tahun di Sekolah Menengah Pertama (SMP) dan 3 tahun di jenjang Sekolah Menengah Atas (SMA).

Adapun untuk pendidikan tingginya yaitu pada jurusan, baik teknik maupun bisnis menetapkan pola pendidikan Ghandi, yaitu pembentukan manusia yang berkepribadian utuh, kreatif dan produktif. Ada istilah S1, 
Agus Setiawan: Analisis Pendidikan Islam di India dan Perbandingannya dengan Pendidikan di Indonesia.

S2 dan juga S3 di India. Ini berlaku sama perguruan tinggi di Indonesia. Hanya saja sistem perkuliahannya yang berbeda juga tugas akhirnya. Kalau di India S1 tidak dituntut untuk menyelesaian akhir seperti skripsi, sedangkan yang diwajibkan hanya pada tingkat S3 yaitu ada tugas wajib pembuatan disertasi.

\section{Simpulan}

Pendidikan di India menggunakan pola dan substansi yang diadobsi dari Negara barat, dimana pertama kali di perkenalkan oleh Negara Inggris pada abad ke-19. Komisi pendidikan India telah menetapkan kebijakan sistem pendidikan 10-2-3 untuk usia sekolah. Tingkat awal 10 tahun terbagi dalam 3 jenjang, yaitu primary (5 tahun), upper primary ( 3 tahun), dan secondary (2 tahun). India memiliki komitmen untuk menyebarluaskan pengetahuan dan kebebasan berfikir di kalangan penduduk yang direfleksikan pada kebijakan dalam undang-undangnya, yaitu pasal 45 dinyatakan bahwa Negara berupaya menyediakan pendidikan secara gratis selama 10 tahun, dan bagi anak-anak hingga mereka berusia 14 tahun.

Otoritas sistem pendidikan ini dipengaruhi oleh Mahatma Ghandi yang memiliki gagasan untuk membentuk "kepribadian yang utuh, kreatif dan produktif". Departemen yang menanggani masalah pendidikan adalah Departemen Pendidikan dan Kesejahteraan. Kualitas pendidikan di India mampu bersaing di dunia internasional tidak muncul dengan tiba-tiba.

Ada beberapa hal yang menjadi faktor pendorong kemajuan dan perkembangan pendidikan di India, di antaranya yaitu: Pertama, universitasuniversitas modern di India sudah berdiri sejak 1857 dan mapan. Kedua, penggunaan Bahasa Inggris sebagai Bahasa pengantar di lembaga-lembaga pendidikan dan lembaga pemerintahan di India. Dan ketiga, dosen India minimal sudah menyelesaikan pendidikan doktor (S-3), bahkan tidak sedikit dari mereka yang menyelesaikan S-2 dan S-3 beberapa kali. Pendidikan di India 
Agus Setiawan: Analisis Pendidikan Islam di India dan Perbandingannya dengan Pendidikan di Indonesia.

dikendalikan oleh pemerintah pusat dan pemerintah daerah yang keduanya bertanggung jawab atas pendidikan dengan kekhususan dimana daerah mempunyai otonomi untuk mengatur hal khusus dalam pendidikan.

Kurikulum Pendidikan Islam India madrasah Islam di India telah menggabungkan kurikulum nasional yang berlaku di negara itu ke dalam lembaga mereka. Modernisasi kurikulum ini memungkinkan adanya perubahan citra madrasah di mata masyarakat India. Muslim India sangat memperhatikan pendidikan, muslim di India sangat mengerti arti sebuah pendidikan bahkan ada yang bersedekah membangun 1 gedung. Semua santri yang sekolah di madrasah di India tidak membayar satu rupees pun dan bahkan siswa mendapatkan beasiswa dari sekolah setiap bulannya. Sebagai contoh lembaga madrasah dan sekolah yang telah ada di India antara lain: Madrasah Dar Al-'Ulum di India dan Sekolah Muhammedan Anglo Oriental College (MAOC) di India. Adapun Perguruan Tinggi Islam di India yang terkenal yaitu Universitas Muslim Aligarh, Jamia Millia Islamia, Universitas Islam Darul Huda yang masih konsisten saat ini dalam bidang pendidikan Islam.

Setidaknya menjadi perbandingan bagaimana pendidikan di India yang Muslimnya minoritas dapat masih berkembang, namun Indonesia dengan penduduk Muslimnya mayoritas ternyata belum mampu bangkit untuk maju dalam hal pendidikan Islam. Ini tentunya menjadi perhatia bersama untuk umat muslim Indonesia agar bisa mengambil manfaat dari pendidikan luar yang bisa diadopsi pada pendidikan Islam Indonesia kedepan sehingga lebih maju dan meningkat. 
Agus Setiawan: Analisis Pendidikan Islam di India dan Perbandingannya dengan Pendidikan di Indonesia.

\section{Daftar Pustaka}

Abdurahman, Dudung. et.al, Sejarah Peradaban Islam dari Masa Klasik Hingga Modern (Yogyakarta: LESFI, 2009.

Akmal, SayyidAhmadKhan ReformisPendidikanIslamDi India JurnalPotensiavol.14 EdisilJanuari-Juni2015.

Al-Azizi, Abdul Syukur. Kitab Sejarah Peradaban Islam Terlengkap. Yogyakarta: Saufa, 2014.

Ali, Mukti. Alam Pikiran Islam Modern di India dan Pakistan. Bandung: Mizan, 1998.

Al-Katttani, Abdul Hayyie dkk, Study In Islamic Countries Panduan Lengkap Kuliah di Negara-negara Islam. Jakarta: Gema Insani, 2009.

Al-Usairy, Ahmad. Sejarah Islam Sejak Zaman Nabi Adam Hingga Abad XX. Akbar Media Eka Sarana, 2003.

Amin,Samsul Munir. Sejarah Peradaban Islam. Jakarta: Sinar Grafika Offset, 2010.

Asmuni, Yusran. Dirasah Islamiah. Jakarta: PT. Raja Grafindo Persada, 1998.

_ . Pengantar Studi Pemikiran dan Gerakan Pembaharuan dalam Dunia Islam. Jakarta: Raja Grafindo Persada, 1998.

Daulay, Haidar Putra. Dinamika Pendidikan Islam di Asia Tenggara. Jakarta: Rineka Cipta, 2009..

Dewan Redaksi Ensiklopedi Islam, Ensiklopedi Islam. Jakarta: PT Ichtiar Baru van Hoeve, 2002.

Ensiklopedi Oxford, Dunia Islam Modern, Jilid 2, Diterjemahkan oleh Eva Y.N, dkk, Bandung, Mizan, 2002.

Fathi, Yakan. Gerakan Islam di Abad Modern, Alih Bahasa: Masrur Zainudin. Jakarta: Media Da'wah. 1987.

Hamka,SejarahUmatIslam. Jakarta: BulanBintang,1981.

http://www.berkuliah.com/2014/06/20-universitas-terfavorit-versi-mahasiswaindonesia-dijelaskan-dengan-sangat-detail-disini.html. Diakses, 23 Maret 2018.

https://id.wikipedia.org/wiki/India,danhtps://ms.wikipedia.org/wiki/PerdanaMe nteriIndia, Diakses pada 13-3-2018.

https://id.wikipedia.org/wiki/Universitas_Islam_Darul_Huda. Diakses, 24 Maret 2018.

Jameelah,

Jurnal Ilmiah Al QALAM, Vol. 12, No. 2, Juli-Desember 2018 
Agus Setiawan: Analisis Pendidikan Islam di India dan Perbandingannya dengan Pendidikan di Indonesia.

Maryam.(MargaretMarcus),IslamdanModernisme,KritikanterhadapBerbag aiUsaha SekulerisasiDunia,terjemahanA.JaimlNuri,Syafiq,A.Mughni. Surabaya:UsahaNasional, 1965.

Khan, Intakhab Alam. Muslim Education in Post-Independent India Issues, Factors and Prospects, Journal of Education and Learning, Vol. 10 (1), 2016

Kumalasari, Dyah. Pengantar Sejarah Pendidikan. Yogyakarta: FISE UNY, 2008.

Lelyveld, David. Aligarh's First Generation. Princeton: Princeton University Press, 1978.

M. Ali Kettani, Minoritas Muslim di Dunia Dewasa Ini. Jakarta: PT.Raja Grafindo Perkasa, 2005.

Ma'arif, Ahmad Syafi'i. Pemikiran dan Peradaban Islam. Yogyakarta: Safiria Insania Press, 2007.

Muhammad, Shan. The Aligarh Movement: Basic Document: 1864-1898. Nachiketa Publication Limited, 1978.

Nasution,Harun.PembaharuandalamIslamSejarahPemikirandanGerakan. Jakarta:BulanBintang, 1982.

SJ, Fadil. Pasang Surut Peradaban Islam dalam Lintas Sejarah. Malang: UIN Malang Press, 2008.

Syaukani, Ahmad.PerkembanganPemikiranModeren di India. Bandung: Pustaka Setia, 1997.

Wawancara dengan Muhammad Wahid, Pengajar Indonesia dari IAIN Samarinda (Magang beberapa bulan), Tanggal. 24-3-2018.

Zakiah, Drajat. Metodologi Pengajaran Agama Islam. Jakarta: Bumi Aksara, 2008. 
Agus Setiawan: Analisis Pendidikan Islam di India dan Perbandingannya dengan Pendidikan di Indonesia.

Jurnal Ilmiah Al QALAM, Vol. 12, No. 2, Juli-Desember 2018 